\title{
Editorial
}

\section{Answer to dengue and chikungunya: specific antiviral therapy}

\author{
Mrinmay Ghosh* \\ Professor, Department of Medicine, Katihar Medical College, Katihar - 854105, Bihar, India \\ *Correspondence: \\ Dr. Mrinmay Ghosh, \\ E-mail: dr.prof.mghosh@gmail.com
}

Copyright: (c) the author(s), publisher and licensee Medip Academy. This is an open-access article distributed under the terms of the Creative Commons Attribution Non-Commercial License, which permits unrestricted non-commercial use, distribution, and reproduction in any medium, provided the original work is properly cited.

Dengue is probably the most important arthropod borne viral disease worldwide, with 50-100 million infections occurring per year. Year-round transmission of dengue viruses of serotype 1-4 is prevalent globally. Vectors are Aedes aegypti and Aedes albopictus. Laboratory diagnosis by ELISA for IgM or RT-PCR, Incubation period 4-7days, sudden onset of fever, frontal headache, retro orbital pain, back pain with severe myalgia, a transient macular rash on the first day, lymphadenopathy, palatal vesicles, scleral infections. Illness may last a week with clinical signs; anorexia, nausea, vomiting, marked cutaneous maculopapular rash on trunks spreading to extremities and face on defervescences on days 3-5. Epistaxis, scattered petechiae and preexisting gastrointestinal lesions may bleed during acute phase. ${ }^{3}$

\section{Complications include}

Pneumonia, bone marrow failure, hepatitis, iritis, retinal hemorrhages, maculopathy, orchitis, oophoritis, depression, chronic fatigue, neurologic complications (such as encephalitis, Guillain-Barre syndrome, phrenic neuropathy, subdural hematoma, transverse hyalites), aplastic anaemia, haemophagocytosis syndrome, rarely stroke, maternal infection poses a risk for premature birth and hemorrhage in both mother and infant if infection occurs near term. Bacterial super infection occurs more commonly in elderly, higher fever, gastrointestinal bleeding, kidney disease and altered consciousness. ${ }^{1,2}$

\section{Causes of death in dengue}

Fulminant hepatitis, acute kidney injury in dengue shock syndrome. Association sequential dengue infection, a risk factor for severity has been confirmed repeatedly in epidemiologic studies from different parts of the world. Several studies suggest severe dengue is more common in a secondary infection with DENV2. During second infection with a different dengue serotype, pre-existing antibody from the first infection fails to neutralize and may enhance viral uptake and replication in mononuclear cells. Resulting higher viral load linked to disease severity. Other factors that may contribute to the pathogenesis of severe dengue include more virulent strains of the virus, host genetic factors, age and comorbidities. $\mathrm{ADE}=$ antibody- dependent immune enhancement theory. Cross-reactive heterotypic antibody is implicated in the occurrence of severe dengue through 'antibody dependent enhancement'. This occurs when the heterologus antibody acquired from a previous infection fails to neutralize the current infecting serotype, instead it enhances viral uptake into Fcy receptor bearing cells, particularly monocytes and macrophages. ADE and facilitating viral entry into cells, also increases viral replication within the cells through alterations of innate and adaptive intracellular antiviral mechanisms. Further work identified that cross-reactive antibodies to the structural precursor membrane protein ( $\mathrm{prM}$ ) formed a major component of $\mathrm{ADE}$, even at higher titres anti-prM antibodies failed to neutralize the virus. A different example of $\mathrm{ADE}$ is in the setting of severe primary dengue in infants born to dengue immune mothers. Decay of the maternally derived $\mathrm{IgG}$ antibody to below neutralization level in infants between age 4-12 months, has been shown epidemiologically and in vitro to cause severe disease through ADE. ${ }^{3}$

In this perspective, it appears imperative to search an appropriate antiviral drug for treatment. The search in literature (history) of pharmacology reveals that Ribavirin, a purine nucleoside analog with a modified base and D-ribose sugar inhibits the replication of a wide range of RNA and DNA viruses, including orthomyxo-, paramyxo-, arena-, bunya-, flaviviruses, influenza viruses, para influenza viruses, respiratory syncytial viruses(iv). Mechanism of action is alteration of cellular 
nucleotide pool, and inhibition of viral messenger RNA synthesis. There was mild rise of hepatic enzyme in the 1 st week, platelet count returns to normal after 2-3 weeks of completion of treatment, mild decrease of appetite in the 1st week: subsided in the 2nd week. Clinical improvement started within 24-36 hours and recovery completed at the end of 5 th day of treatment. ${ }^{4,5}$

Dosage: 15 to $20 \mathrm{mg} / \mathrm{Kg}$ body weight/day in 2-3 divided doses, orally. During the course of treatment supportive measures with oral rehydration salt solution 1-2 litres was advised. All the patients who came with hypotension, edema and hemorrhage responded after $3^{\text {rd }}$ dose of Ribavirin. Ribavirin was available in medicine counters in the form of syrup, capsules and tablets. Only cold sponging and ice cap were sufficient to reduce the surface temperature. There was no need of antipyretics nor Acetaminophen which led to hypothermia and subsequent relapse of fever with shivering and rigor leading to confusion to the clinicians and development of azotemia. Encouraged by the excellent results of Ribavirin therapy, subsequent use of this drug in measles, measles with encephalopathy, measles with bronchopneumonia, mumps, mumps with pancreatitis, mumps with encephalopathy, mumps with orchitis; was highly encouraging (number of cases $>50$ ). Two cases of Rabies with ascending paralysis and one case of Japanese Encephalitis with coma were recovered with Ribavirin therapy $(30 \mathrm{mg} / \mathrm{Kg} /$ day for 4 weeks with no residual deficit; along with zinc and multivitamin supplements).

The author Professor Dr. Mrinmay Ghosh, M.D., PhD., was then Professor of Medicine in Infectious Disease and Beliaghata General Hospital, Calcutta, West Bengal, India (2004-2013). The state of West Bengal was endemic for dengue and Chikungunya with outbreaks of both during his tenure. About 1500 dengue cases and 200 Chikungunya cases were admitted in the hospital for treatment. All the cases recovered successfully (except one DHS and one DSS) and completely without any residual complication.

\section{Funding: No funding sources}

Conflict of interest: None declared

Ethical approval: The study was approved by the institutional ethics committee

\section{REFERENCES}

1. Harrison's Principles of Internal Medicine, Nineteenth Edition, Pub. Mc Graw Hill; 2015:13181319.

2. Current Medical Diagnosis and Treatment: Pub. Mc Graw Hill; 2014:1340.

3. Manson's Tropical Diseases, Ed. 23 ${ }^{\text {rd }}$ Pub. ELSEVIER, Saunders; 2014:162-70.

4. Hardman JG, Limbard LE. Ribavarin inhibits the replication of wide range of RNA and DNA viruses including orthomyxo, paramyxo, arena, bunya, flavi, hepres, adeno, pox and retroviruses. Goodman \& Gilman's: the pharmacological basis of therapeutics. $10^{\text {th }}$ Ed. Mcgraw Hill. 2001;1336-37.

5. Tam RC, Lau JY, Hong Z. Mechanism of action of Ribavirin in antiviral therapies. Antiviral Chemother. 2002;12:261-72.

6. Goodman and Gilman's: The Pharmacological Basis of Therapeutics, Eds: Joel G. Hardman, Lee E. Limbard, Tenth Edition Pub. Mc. Graw Hill; 2001:1336-7.

Cite this article as: Ghosh M. Answer to dengue and chikungunya: specific antiviral therapy. Int J Adv Med 2017;4:603-4. 